\title{
PENGEMBANGAN OBJEK WAKAF DALAM FIQIH ISLAM DAN HUKUM POSITIF DI INDONESIA
}

\author{
Abdul Haris Naim \\ Sekolah Tinggi Agama Islam Negeri (STAIN) Kudus \\ e-mail: harisnaim869@gmail.com
}

\begin{abstract}
In jurisprudence there is an idea of waqf mu'aqqat (waqf only in a certain duration). Imam Malik argues that the waqf contract is Mulazamat (the possession of a waqf object passes from wakif belongs to God-general). However, he argues that waqf is not necessarily done by Mu'abbad (forever); it may be done within a certain period of time, provided that the waqf shall not be withdrawn until the agreed duration is completed. Indonesian Muslims for hundreds of years have already identified waqf with (in the form of) land, and movable objects of a long lasting nature. Thus, Law no. 41 of 2004 and PP No. 42/2006 is projected as a means of social engineering (social engineering), make changes in thoughts, attitudes and behavior of Muslims to breathe with the spirit of the Act. One of the new regulations in the Waqf Act is the development of waqf objects.
\end{abstract}

Keywords: Waqf Objects, Figh, and Regulation 


\section{Pendahuluan}

Undang-Undang Republik Indonesia No. 41 tahun 2004 tentang Wakaf dan PP No 42/2006, diarahkan untuk memberdayakan wakaf yang merupakan salah satu instrumen dalam membangun kehidupan sosial ekonomi umat Islam. Kehadiran Undang-undang wakaf ini menjadi momentum pemberdayaan wakaf secara produktif serta perluasan pemaknaan obyek wakaf, sebab di dalamnya terkandung pemahaman yang komprehensif dan pola manajemen pemberdayaan potensi wakaf secara modern.

Apabila dalam perundang-undangan sebelumnya, PP No.28 tahun 1977 tentang Perwakafan Tanah Milik, konsep wakaf identik dengan tanah milik, maka dalam Undang-Undang Wakaf yang baru ini konsep wakaf mengandung dimensi yang sangat luas. Ia mencakup harta tidak bergerak maupun yang bergerak, termasuk wakaf uang yang penggunaannya sangat luas, tidak terbatas untuk pendirian tempat ibadah dan sosial keagamaan. Formulasi hukum yang demikian, jelas suatu perubahan yang sangat revolusioner dan jika dapat direalisasikan akan memiliki akibat yang berlipat ganda atau multiplier effect, terutama dalam kaitannya dengan pemberdayaan ekonomi umat Islam.

Namun usaha ke arah itu jelas bukan pekerjaan yang mudah. Umat Islam Indonesia selama ratusan tahun sudah terlanjur mengidentikkan wakaf dengan (dalam bentuk) tanah, dan benda bergerak yang sifatnya bendanya tahan lama. Dengan demikian, UU No. 41 tahun 2004 dan PP No 42/2006 diproyeksikan sebagai sarana rekayasa sosial (social engineering), melakukan perubahan-perubahan pemikiran, sikap dan perilaku umat Islam agar senafas dengan semangat UU tersebut (Satjipto Rahardjo, 1986: 117). Salah satu regulasi baru dalam UndangUndang Wakaf tersebut adalah pengembangan objek wakaf.

Artikel ini akan membahas pengembangan obyek wakaf baik dari sisi hukum Islam maupun hukum positif. 


\section{Pengembangan Objek Wakaf dalam Fiqih Islam dan Hukum Positif....}

\section{Pembahasan}

\section{Pengertian wakaf}

Secara etimologis, kata waqf adalah bentuk mashdar (noun verbal) dari kata kerja waqafa - yaqifu, yang artinya diddu istamarr, berhenti (Ahmad Warson, 1984: 1683). Secara lexicografis, kata al-waqfu sama artinya dengan at-tahbisu dan attasbilu, yaitu alhabsu anit-tasharrufi (mencegah agar tidak mengatur) (Wahbah Az-Zuhaily, 1989: 153). Kata waqofa bisa berbentuk mutāaddy dan bisa juga berbentuk lazim. Dalam bentuk mutāaddy seperti pada ungkapan waqoftusy-syai'a, yang berarti habastu fi sabilillahi (mewakafkan sesuatu). Sedang dalam bentuk lazim seperti pada ungkapan waqoftu (saya berhenti) (Ahmad Warson, 1984: 1683). Kata habs, seperti juga kata waqf adalah bentuk mashdar dari kata kerja habasa - yahbisu, yang artinya menahan. Namun demikian, keduanya mempunyai perbedaan. Perbedaan itu ialah bahwa kata habasa dapat dijadikan bentuk tsulatsi mazid, sehingga menjadi ahbasa, tetapi bukan habbasa. Sementara kata waqafa bila dijadikan bentuk tsulatsi mazid menjadi waqqafa, bukan awqafa. Sebab, kata habbasa maupun awqafa merupakan ungkapan yang tidak lazim dipergunakan dalam linguistik bahsa Arab, kecuali untuk hal-hal yang berkonotasi negatif, rendah, atau hina. Misalnya ungkapan al-mauqifu li habsin nasifihi lil-hisabi (tempat untuk menahan orang, guna diadakan perhitungan). Kemudian, kata waqf dibatasi penggunaanya hanya pada obyek tertentu, yakni benda wakaf, sehingga kata al-waqfu disamakan pengertiannya dengan al-habsu. Oleh karena itu, di Marokko ada suatu jabatan yang dinamakan waziru al-habsi, yang berarti Menteri Wakaf (Wahbah Az-Zuhaily, 1989: 153).

Dalam perspektif hukum Islam (figh) wakaf adalah institusi ibadah sosial yang tidak memiliki rujukan ekplisit dalam al-Quran dan al-Sunnah. Ulama berpendapat bahwa perintah wakaf merupakan bagian dari perintah untuk melakukan alKhayr (secara harfiah berarti kebaikan ). Allah berfirman yang artinya: "Hai orang-orang yang beriman rukulah, dan sujudlah, serta 
beribadahlah kamu sekalian kepada Tuhanmu, dan berbuatlah kebaikan supaya kamu mendapat kemenangan". (QS. Al-Baqarah: 43)

Jumlah kitab fiqh sangat banyak karena fiqih merupakan bagian dari ajaran agama Islam yang hidup dan berkembang dalam masyarakat Islam di berbagai penjuru dunia. Oleh karena itu, mengutip semua kitab fiqih dalam rangka menjelaskan kriteria wakaf menurut pakar fiqih Islam, tidaklah mungkin dalam tulisan pendek ini. Akan tetapi yang paling mungkin adalah mengutif sebagiannya saja.

Taqiy al-Din Abi Bakr Ibn Muhammad al-Husaini alDimasqi menafsirkan bahwa perintah untuk berbuat baik (alkhayr) berarti perintah untuk melakukan waqaf (Taqiyah al-Din Abi Bakr Ibn Muhammad al-Husaini al-Dimasqi, tt.: 319). Penafsiran Taqiy al- Din Abi bakr Muhammad al-Husaini al-Dimasqi tersebut relevan apabila dihubungkan (munasabat) dengan firman Allah tentang wasiat (QS. Al- Baqarah: 180). Dalam ayat tersebut, kata al- khayr diartikan dengan "harta benda". Oleh karena itu, perintah melakukan al-khayr berarti perintah untuk melakukan ibadah bendawi.

Dalam hadis dikatakan bahwa wakaf disebut dengan sedekah jariah (shadaqat jariyat) dan al-habs (harta yang pokoknya dikelola dan hasilnya didermakan) (Imam Muslim, tt.: 14). Oleh karena itu, nomenklatur wakaf dalam kitab- kitab hadis dan fiqih tidak seragam. Al-Syarkhasi dalam kitab al-Mabsuth, memberikan nomenklatur wakaf dengan Kitab al-Waqf (Abi Bakr Muhammad Ibn Ahmad Ibn Sahl al-Syarkhasi, 2001: 33-34), Imam Malik menuliskannya dengan nomenklatur Kitab al-Habs wa al-Shadaqat (Imam Malik Ibn Anas, tt.: 417), Imam al-Syafi'i dalam al-Umm memberikan nomenklatur wakaf dengan al-Ahbas (Muhammad Ibn Idris al-Syafi' $i$, tt.: 51), dan bahkan Imam Bukhari menyertakan hadis-hadis tentang wakaf dengan nomenklatur Kitab al-Washaya (Imam Bukhari, 1981: 185-199). Oleh karena itu, secara teknis wakaf disebut dengan al-ahbas, shadaqat jariyat, dan al-waqf. Secara normatif idiologis dan sosiologis perbedaan nomenklatur wakaf 
tersebut dapat dibenarkan, karena landasan normatif perwakafan secara ekplisit tidak terdapat dalam al-Quran atau al-Sunnah dan kondisi masyarakat pada waktu itu menuntut akan adanya hal tersebut. Oleh karena itu, wilayah Ijtihadi dalam bidang wakaf lebih besar dari pada wilayah Tauqifi-nya. Pembahasan mengenai pengembangan objek wakaf menunjukan dua hal: Pertama, objek wakaf itu sudah ada ketentuannya dalam berbagai kitab fiqih dengan pendapat yang beragam dan dalam berbagai peraturan perundang- undangan yang dibentuk oleh pemerintah, dan Kedua, perkembangan teknologi dan peradaban manusia mendorong adanya perubahan cara pandang yang berimbas pada perluasan pemaknaan harta (al-amwal), sehingga pengembangan objek wakaf dipahami sebagai perluasan cakupan benda wakaf yang sudah dijelaskan oleh ulama sebelumnya.

\section{Obyek wakaf}

Sayyid Sabiq menjelaskan bahwa benda, baik bersifat tetap (al-Uqar), maupun bergerak (al-Manqul) seperti perlengkapan rumah, mashahif, buku- buku, senjata, dan kendaraan boleh dijadikan objek wakaf. Disamping itu, setiap benda yang boleh diperdagangkan dan dimanfaatkan (dengan tetap kekal zatnya), boleh juga dijadikan objek wakaf. Sebaliknya, al- Sayyid Sabiq berpendapat bahwa benda yang rusak (berubah) karena dimanfaatkan seperti uang, lilin, makanan dan minuman, tidak syah untuk dijadikan objek wakaf. Disamping itu, al-Sayyid Sabiq menjelaskan bahwa benda- benda yang tidak boleh dijual karena zatnya seperti anjing, babi, dan binatang buas, dan tidak boleh dijual karena yang lain seperti karena digadaikan, tidak boleh dijadikan objek wakaf (Sayyid Sabiq, 1983: 382).

Muhammad Mushthafa Syalabi menjelaskan bahwa syarat- syarat objek wakaf ada empat: Pertama, harta tersebut harus mutaqawwim (memungkinkan untuk dijaga atau dipelihara dan memungkinkan untuk dimanfaatkan dengan cara tertentu); Kedua, harta yang diwakafkan dapat diketahui secara sempurna 
oleh wakif dan pengelola (penerima) wakaf ketika wakaf diikrarkan; Ketiga, benda yang diwakafkan adalah milik wakif secara sempurna dan dapat dipindah tangankan ketika benda tersebut diikrarkan untuk wakaf; Keempat, benda yang diwakafkan dapat dipisahkan secara tegas tanpa terikat dengan yang lain (Muhammad Mushthafa Salabi, 1957: 54-47). Pendapat ulama fiqih mengenai objek wakaf memperlihatkan bahwa syarat-syarat benda wakaf (harus benda, bermanfaat, tidak sekali pakai, tidak haram zatnya, dan harus milik wakif secara sempurna) tidak didukung hadis secara khusus dan mereka menggunakan ayatayat Al-Quran dan Hadis yang bersifat umum. Oleh karna itu, penentuan syarat-syarat objek wakaf termasuk wilayah ijtihadi.

Sekarang uang menempati posisi penting dalam kegiatan transaksi ekonomi di berbagai negara di dunia, karena uang sekarang tidak hanya berfungsi sebagai alat tukar, tetapi sudah dianggap sebagai benda yang meskipun terjadi silang pendapat di antara pakar fiqih dapat diperdagangkan. Oleh karena itu, ulama di pakistan, Abdul Manan, sudah membolehkan adanya wakaf uang dengan istilah cash waqf (yang diterjemahkan ke dalam bahasa Indonesia menjadi wakaf tunai), terjemahannya agak keliru karena mengaburkan gagasan pokoknya.

Dewasa ini, uang sudah bergeser fungsi, pada awalnya ia hanya berfungsi sebagai alat tukar, sekarang ia sudah menjadi sesuatu yang diperjualbelikan di berbagai bank dan money changer. Oleh karena itu, uang sudah sama kedudukannya dengan benda lain yang dapat diperjualbelikan. Dengan kenyataan yang demikian, pernyataan Al-Sayyid Sabiq yang menyatakan bahwa uang didak dapat dijadikan objek wakaf menjadi paradoks dengan pernyataannya sendiri, yaitu uang dapat dijadikan objek perdagangan. Oleh karena itu, Juhaya S. Praja juga berpendapat bahwa uang boleh dijadikan objek wakaf (Juhaya S. Praja, 1993: 13). Abdullah Gimnastiar telah mempraktekkan gagasan ini dengan cara melelang tanah yang akan dibeli untuk pengembangan pesantren Daruttauhid dengan cara menghargakan 
tanah permeternya sehingga wakif dapat membayar tanah tersebut sesuai dengan kemampuannya melalui nomor rekening bank yang sudah disiapkan oleh panitia. Meskipun akad yang dilakukan adalah wakaf tanah, akan tetapi praktiknya yang diberikan oleh wakif adalah uang.

Dalam fikih terdapat gagasan mengenai wakaf mu'aqqat (wakaf hanya dalam durasi tertentu). Imam Malik berpendapat bahwa akad wakaf bersifat Mulazamat (kepemilikan benda wakaf berpindah dari milik wakif menjadi milik Allah-umum). Akan tetapi, beliau berpendapat bawa wakaf tidak mesti dilakukan secara mu'abbad (untuk selamanya); ia boleh dilakukan dalam tenggang waktun tertentu, dengan syarat, wakaf tersebut tidak boleh ditarik sebelum durasi yang disepakati selesai. Oleh karena itu, sebagai lanjutan dari gagasan mengenai wakaf uang, boleh saja seorang muslim mewakafkan sejumlah uang (misalnya 1 triliyun) selama lima tahun kepada pendidikan pesantren. Uang 1 triliyun tersebut kemudian disimpan di Bank yang kemudian menggunakan sistem syariah dalam bentuk deposito; sehingga lembaga pendidikan yang berperan sebagai nadzir dapat menggunakan uang hasil simpanan dalam bentuk depositomudharabah di Bank-Bank yang menggunakan sistem syariah. Suatu gagasan cerdas dari Imam malik adalah bahwa tidak boleh ditarik sebelum tenggang waktu yang disepakati selesai (Juhaya S. Praja, 1993: 18). Pendapat ini dapat memberikan kepastian kepada nadzir mengenai tenggang waktu deposito uang di Bank sistem syariah.

Gagasan ini pada dasarnya sama dengan gagasan wakaf uang. Akan tetapi, realitas kadang menunjukan bahwa kehidupan seseorang itu mengalami fluktuasi dalam berbagai hal, termasuk dalam kemampuan mengatur finansial. Tidak menutup kemungkinan adanya seseorang yang pada awalnya kaya, kemudian mewakafkan benda miliknya ketika kaya, dan setelah itu usahanya bangkrut dan jatuh miskin. Oleh karena itu, adanya orang yang khawatir terhadap realitas yang demikian merupakan 
hal yang wajar, dan kekhawatiran itu tidak membuat pintu untuk melakukan wakaf tertutup ia diberi uang untuk melakukan ibadah wakaf yang tidak mu'abbad.

Di Indonesia terdapat dua Ormas Islam yang telah memfatwakan hak cipta, yaitu Bahtsul Masa'il NU dan Komisi Fatwa MUI. Dalam Muktamar NU ke-28 yang dilaksanakan dipondok pesantren Krapyak Yogyakarta pada tanggal 2528 Nopember 1998 (26-29 Rabi'ul Akhir 1410 H) ditetapkan 23 keputusan yang merupakna hasil pembahasan dari Lajnah Bahtsul Masa'il NU, salah satunya adalah kedudukan hak cipta dalam konteks pembagian harta pusaka apakah hak cipta dapat berkedudukan sebagai tirkah (harta peninggalan) atau tidak, dan apakah ia harus dikeluarkan zakatnya?

Bahthsul Masa'il NU menetapkan bahwa hak cipta dalam hukum waris dapat dijadikan harta peninggalan. Adapun kaitannya dengan zakat, Bahtsul Masa'il NU menetapkan bahwa ia (hak cipta) sama dengan harta biasa. Pada tanggal 17-21 Nopember 1997, diadakan Musyawarah Nasional Alim Ulama dan Konferensi Besar Nahdatul Ulama yang diselenggarakan di pondok pesantren Qamarul Huda. Desa Bagu, Pringgarata, Lombok Tengah Nusa Tenggara Barat. Salah satu keputusan Bahtsul Masa'il NU dalam acara tersebut adalah hukum hak cipta. Jadi, keputusan Bahtsul Masa'il NU tentang hak cipta yang pertama berkenaan dengan kedudukannya sebagai harta pusaka, sedangkan keputusan yang kedua berkenaan dengan hukumnya, lebih tepatnya hukum hak cipta karya tulis.

Bahthsul Masa'il NU menetapkan bahwa: (1) hak cipta dlindungi oleh hukum Islam sebagai hak milik dan dapat menjadi harta peninggalan bagi ahli warisnya; (2) hukum mencetak dan menerbitkan karya tulis pihak lain adalah boleh selama ada izin dari pemilik hak, pengarang, penulis, ahli waris, atau yang menguasi hak cipta tersebut, dan (3) apabila pemilik hak, pengarang, penulis, ahli waris, atau yang menguasai hak cipta tersebut sudah tidak ada, maka karya tulis tersebut menjadi milik 
umat Islam. Dengan memperhatikan keputusan Bathsul Masa'il NU tersebut diketahui bahwa kedudukan hak cipta adalah sebagai hak milik yang hukumnya sepadan dengan benda milik.

Ormas Islam kedua yang menfatwakan hak cipta adalah komisi Fatwa MUI. Pada tanggal 18 Januari 2003 (14 Zulqa'dah 1423 H.), Komisi Fatwa MUI mengeluarkan fatwa Nomor 1 Tahun 2003 tentang Hak Cipta. Setelah mempertimbangkan dalil Al-Quran, Hadis , Kaidah Fiqih, pendapat ulama, pakar atau ahli, penjelasan dari pihak-pihak yang berkepentingan, dan peraturan perundang-undangan, akhirnya Komisi Fatwa menetapkan bahwa: (1) hak cipta dipandang sebagai salah satu hak kekayaan (huquq maliyat) yang mendapat perlindungan hukum (mashun) sebagai kekayaan (mal); (2) hak cipta yang dilindungi oleh hukum Islam adalah hak cipta atas ciptaan yang tidak bertentangan dengan hukum Islam; (3) hak cipta dapat dijadikan objek wakaf (ma"qud "alayh), baik akad pertukaran baik komersial ( $m u$ "awadhat), maupun akad nonkomersial (tabarru"at), serta dapat diwariskan dan diwakafkan dan; (4) setiap bentuk pelanggaran terhadap hak cipta terutama pembajakan merupakan kezaliman yang hukumnya adalah haram.

Fatwa ini secara sosiologis berkenaan langsung dengan realitas di masyarakat mengenai pembajakan yang berimbasnya pada kurang bergairahnya masyarakat dalam melahirkan ciptaanciptaan ( termasuk temuan) karena proses untuk menciptakan sesuatu begitu sulit tetapi ketika ciptaan itu sudah ada, para pembajak dengan seenaknya menggunakan ciptaan-ciptaan tersebut tanpa memiliki imbas kepada penciptanya. Dalam kasus penciptaan lagu, yang kaya adalah penyanyinya, sedangkan finansial para pencipta lagu cenderung "seret" dan pas-pasan. Oleh karena itu, pembajakan tidak sejalan dengan prinsip amal shaleh yang ada dalam Islam.

Kerangka pemikiran tersebut bahwa fiqih sebagai produk pemikiran manusia bukan sesuatu yang rentan terhadap perubahan, karena fiqih harus mempu memberikan jawaban 
yuridis terhadap berbagai persoalan hidup dan kehidupan manusia, sementara dinamika kehidupan senantiasa menimbulkan perubahan-perubahan.

\section{Obyek wakaf dalam Undang-undang Nomor 41 Tahun 2004}

Kelahiran Undang-Undang No. 41 Tahun 2004 tentang Wakaf, merupakan fiqih Indonesia sebagai hasil ijtihad para ulama Indonesia yang sesuai dengan kebutuhan dan seting sosial pada saat ini. Tetapi ijtihad ulama-ulama Indonesia ini tidak bisa membatalkan ijtihad ualam-ulama fiqih terdahulu. Hal ini sesuai dengan kaidah kuliyyah: "Ijtihad tidak bisa batal dengan ijtihad." "Ijtihat tidak bisa batal dengan itjihad yang sama."

Ijtihad fuqaha terdahulu terhadap objek wakaf bertujuan untuk kemaslahatan umat sesuai denga setting sosial pada saat itu. Begitu pula ijtihad ulama-ulama Indonesia terhadap pengembangan objek wakaf adalah demi kemaslahatan umat manusia yang disesuaikan dengan kebutuhan dan setting sosial pada saat ini. Sebab pada dasarnya hukum adalah artikulasi dari pemikiran dan kegiatan manusia pada zamannya. Sementara dinamika kehidupan manusia senantiasa berubah. Oleh karena itu, sikap yang perlu harus dipegang dalam memahami pengembangan objek wakaf adalah kaidah: "Kita harus senantiasa respek dan respon terhadap hasil pemikiran ulama terdahulu yang baik, tetapi kita harus mencoba menemukan penemuan baru yang lebih baik atau lebih mashlahat."

Namun dalam tataran realita masih dijumpai variasai dalam dalam menetapkan masalah wakaf antara Perundangundangan yang berlaku dan hukum Islam. Dan ternyata pada saat ini telah terjadi pergeseran atau perluasan pengertian tentang wakaf dari apa yang dikenal dan dirumuskan dalam fiqih Islam maupun PP No. 28 Tahun 1977.

Dengan demikian haruskah pemahaman terhadap pengembangan objek wakaf (benda wakaf) bersifat tektual atau literal terhadap pendapat fuqaha terdahulu? Bukankah zaman 
selalu berubah sesuai dengan dinamika masyarakat yang selalu berkembang? Bagaimana kompetensi Peradilan Agama terhadap pengembangan objek wakaf yang diatur dalam Pasal 16 UndangUndang No. 41 Tahun 2004? Apakah kewenangan Peradilan Agama bersifat totalitas atau hanya bersifat parsial terutama terhadap pengembangan objek wakaf yang bergerak seperti wakaf uang, wakaf surat berharga, wakaf hak atas kekayaan inteletual, wakaf hak sewa. Sebab pada dasarnya objek wakaf benda bergerak tersebut jika terjadi sengketa hak milik akan sangat bersinggungan dengan hukum perdata umum atau bahkan hukum pidana, sementara kewenangan peradilan agama dibatasi hanya perdata Islam saja.

Pertanyaan-pertanyaan tersebut dapat dijadikan kerangka paradigmatik bagi para hakim agama dalam memahami pengembangan objek wakaf dalam wacana fiqih Islam hubungannya dengan hukum positif di Indonesia dan perkembangan kemasyarakatan, untuk mengetahui jangkauan kewenangan peradilan agama dalam menangani sengketa wakaf. Oleh karena itu, dari pengembangan objek wakaf perlu dicari nilai filosofisnya atau menurut istilah Fazlul Rahman "Ideal Moral" dari adanya pengembangan objek wakaf tersebut. Sebab ketika pengembangan objek wakaf ditranformasikan ke dalam tataran praktis tanpa melihat nilai dasar perwakafan, dapat menyebabkan terjadinya penyimpangan dari tujuan wakaf itu sendiri. Objek wakaf dalam perwakafan tidak lebih sebagai instrumen untuk menyediakan berbagai sarana ibadah sosial dan atau menjadi kekuatan ekonomi untuk memajukan kesejahteraan umum.

Sebagai sebuah instrumen, formula-formula objek perwakafan akan sangat mungkin untuk berubah dan diformulasikan kembali seiring dengan perubahan persepsi masyarakat. Formula perwakafan yang ditawarkan oleh para ulama fiqih terdahulu merupakan hasil pemahaman dan interpretasi "nash" dengan melihat kondisi masyarakat pada waktu itu. Sebagaimana diketahui, produk hukum pada dasarnya 
merupakan artikulasi dari keinginan masyarakat yang ada. Sementara itu transformasi sosial dengan berbagai dinamikanya telah berubah.

Perubahan sosial pada lembaga perwakafan dapat dilihat bahwa sekarang perwakafan harus memiliki peran sosial yang lebih baik, dan memiliki implikasi positif. Terjaminya status hukum objek wakaf bagi para pihak yang berkaitan dengan perwakafan, adanya ketertiban dari segi prosedural, tekhnik dan administratif di bidang penyelenggaraan perwakafan, dan menjamin maksimalisasi perolehan manfaat secara optimal dengan tetap memperhatikan azas dan hukum syari'at Islam. Adanya implikasi ekonomis yang signifikan sebagai hasil dari pemanfaatan harta benda wakaf (obyek wakaf) yang selanjutnya akan dapat mengangkat harkat dan martabat masyarakat ke arah yang lebih baik.

Perwakafan sekarang harus mendorong terbentuknya azas transparansi, akuntabilitas, dan profesionalisme dalam pengelolaanya. Dengan demikian perwakafan yang merupakan transformasi vertikal ibadah lillahi ta"ala, akan menjadi lebih bersifat horizontal yang berguna bagi kesejahteraan umum.

Di antara perubahan sosial lain dalam perwakafan adalah terjadinya pengembangan obyek wakaf (benda wakaf) seperti bolehnya wakaf tunai atau uang. Wakaf tunai atau uang merupakan hal yang baru dan belum di kenal masyarakat, oleh karena itu perlu pengelolaan yang tepat oleh lembaga keuangan syariah untuk menjamin transparanasi, likuiditas dan akuntabilitas. Di dalam wakaf uang ini harus ada lembaga penjamin, mengingat harta benda wakaf bukan sesuatu yang langsung habis. Lembaga penjamin terhadap wakaf uang adalah untuk mengantisipasi kemungkinanan habisnya benda wakaf ini jika mengalami pailit. Di samping itu, sebagai lembaga keagamaan wakaf hendaknya dapat di laksanakan tidak sebatas untuk menyediakan sarana ibadah dan sosial, melainkan juga memiliki kekuatan ekonomi untuk memajukan kesehjatraan umum. 
Masalah pengembangan obyek wakaf tersebut harus mendapat respon yuridis, terlebih bagi Indonesia yang dalam kontitusinya mendeklarasikan sebagai negara hukum (recht staat). Konsekuensinya penegakan hukum pada lembaga yudikatif harus berdasarkan pada azas legalitas, yakni pengadilan mengadili berdasarkan aturan hukum yang ada (rule of law), bukan menurut selera atau kemauan hukum (M. Yahya Harahap, 1997: 69).

Masyarakat dan ketertibannya merupakan dua hal yang berhubungan erat, bahkan dapat di katakan dua sisi dari satu mata uang. Sulit untuk mengatakan adanya masyarakat tanpa adanya suatu ketertiban (Sajtipto Raharjo, 1996: 13). Ketertiban dan keteraturan dalam masyarakat akan mengejawantah apabila di dukung adanya suatu tatanan. Tatanan inilah yang menciptakan hubungan-hubungan yang tetap dan teratur antara anggota- anggota masyarakat yang memiliki kompleksitas yang tinggi, sehingga konflik kepentingan diantara entitas masyarakat tersebut merupakan keniscayaan.

Dalam analisis Satjipto Raharjo, tatanan yang merupakan instrumen untuk mewujudkan ketertiban tersebut adalah kebiasaan, hukum dan kesusilaan (Sajtipto Raharjo, 1996: 14-17). Diantara ketiga tatanan tersebut, hukum merupakan institusi yang mencerminkan kehendak manusia bagaimana sebuah kondisi di ciptakan. Ia mengintegrasikan dan mengkoordinasikan kepentingan-kepentingan yang bersinggungan, sehinga confik of intereset bisa diminimalisir, dan hukum dapat mewujudkan keadilan, kegunaan, dan kepastian hukum. Untuk merealisasikan hal tersebut hukum harus di tegakan. Penegakan hukum (law eforcement) ini kemudian menjadi suatu yang sangat penting. Hal ini karena cita- cita hukum sangat tergantung pada penegakannya. Dalam struktur kenegaraan modern, tugas penegakan hukum (law enforcement) ini di laksanakan oleh peradilan (yudikatif), dengan kaidah- kaidah penyelenggaraannya. Sesuai dengan Pasal 10 UU No. 4 Tahun 2004 tentang Pokok-Pokok Kekuasaan Kehakiman, yang di maksud dengan badan-badan peradilan tersebut adalah 
Peradilan Umum, Peradilan Agama, Peradilan Militer dan Peradilan Tata Usaha Negara. Salah satu tugas dari peradilan di maksud adalah untuk meluruskan kembali norma- norma hukum yang terlangar. Karena dengan terlanggarnya hukum akan mengakibatkan timbulnya perselisihan-perselisihan yang akan mengakibatkan pula terganggunya keefektifan komunikasi antara sesama anggota masyarakat dan negara. Keempat badan peradilan ini dalam relasi pelaksanaan tugasnya masing-masing mempunyai wewenang dan kompetinsi tertentu.

Kewenangan Peradilan Agama antara lain di atur dalam pasal 49 UU No 3 Tahun 2006 yang menyebutkan bahwa yuridiskasi peradilan agama ini antara lain meliputi bidang wakaf. Adapun hukum positif yang mengatur perwakafan di Indonesia sebelum Tahun 2004 adalah UU PA No. 5 Tahun 1960 Pasal 49 ayat (1) sampai (3), jo PP No. 28 Tahun 1978 tentang Perwakafan Tanah Milik, Peraturan Menteri Agama No. 1 Tahun 1978 tentang Peraturan Pelaksanaan PP No. 28 Tahun 1978 dan Kompilasi Hukum Islam buku III, dan masih banyak peraturan lain. Namun semua peraturan perundang- undangan tersebut belum menjelaskan secara pasti mengenai persoalan pengembangan obyek wakaf (benda wakaf).

Sebagai salah satu dari reformasi hukum adalah lahirnya Undang- Undang Republik Indonesia Nomor 41 Tahun 2004 tentang Wakaf. Dalam Pasal 16 Ayat (1) Sampai (3) menyebutkan bahwa obyek wakaf (benda wakaf) terdiri dari benda tidak bergerak dan benda bergerak .

Benda tidak bergerak meliputi:

1. Hak atas tanah sesuai dengan ketentuan peraturan perundang- undangan yang berlaku baik yang sudah maupun yang belum terdaftar;

2. Bangunan atau bagian dari bangunan yang terdiri atas tanah sebagaimana dimaksud pada huruf a;

3. Tanaman dan benda lain yang berkaitan dengan tanah; 
4. Hak milik atas satuan rumah susun sesuai dengan ketentuan peraturan perundang- undangan yang berlaku;

5. Benda tidak bergerak lain dengan ketentuan Syariah dan peraturan Perundang- undangan yang berlaku.

Sedangkan benda bergerak meliputi:

1. Uang;

2. Logam Mulia;

3. Surat Berharga;

4. Kendaraan;

5. Hak Atas Kekayaan Intelektual;

6. Hak Sewa;

7. Benda bergerak lain sesuai dengan ketentuan Syariah dan Peraturan Perundang- undangan yang berlaku.

\section{Peran Pengadilan Agama}

Peradilan Agama semakin diperluas peranannya untuk ikut menangani sengketa pengelolaan zakat, wakaf, dan bisnis syariah. Menurut Djubaedah salah satu anggota Komisi Hukum Majelis Ulama Indonesia mengatakan bahwa Undang-Undang No. 41 Tahun 2004 Tentang wakaf tidak mewajibkan membawa Sengketa Ke Pengadilan Agama atau Mahkamah Syariah. Akan tetapi bila dibawa ke peradilan umum, apakah peradilan umum akan memahami wakaf yang diatur dalam konsepsi hukum Islam. Sengketa dalam masalah Muamalah yang diatur oleh syariat Islam merupakan wilayah kewenangan Peradilan Agama, sementara sengketa wakaf sekarang bisa terjadi misalnya ketika terjadi kesalahan dalam pencatatan atau pengelolaan dana wakaf. Dalam hal ini bisa terjadi pelanggaran perdata maupun pidana.

Oleh karena itu, pengembangan obyek wakaf (benda wakaf) yang menjadi beban hukum baru bagi peradilan agama sangat menarik untuk terus dikaji lebih mendalam sehingga para Hakim Peradilan Agama dapat memperoleh suatu cakrawala pandang 
yang lebih luas dan komprehensip tentang pengembangan objek wakaf dan permasalahan hukum baru yang akan ditimbulkannya. Sehingga ketika dikemudian hari muncul masalah hukum wakaf yang kemungkinan sangat tipis titik singgungnya dengan perkara pidana, terutama benda wakaf yang bergerak, para Hakim Peradilan Agama dapat mengkontruksi hukum dalam sebuah putusan peradilan agama yang sesuai dengan rasa keadilan hukum, kegunaan hukum, dan kepastian hukum.

Cita-cita ideal tersebut di atas, bahwa Hakim Peradilan Agama harus mengedepankan intelektualitas, profesionalitas, dan moralitas dalam mengkontruksi hukum sesuai dengan rasa keadilan, kegunaan, dan kepastian hukum, hanya akan menjadi sebuah Authopia saja, apabila pihak yang memiliki tanggung jawab moral untuk meningkatkan kualitas Hakim Peradilan Agama tidak segera mengambil langkah nyata dalam mencapai citacita tersebut. Sebab permasalahan hukum wakaf saat ini sangat berbeda dengan permasalahan hukum wakaf masa lalu. Apakah hakim peradilan agama sudah memahami secara komprehensip tentang konsepsi cash waqf misalnya, bagaimana bentuk dan mekanismenya? Aspek mana yang rentan terhadap timbulnya permasalahan hukum? Begitu pula konsepsi wakaf logam mulia, wakaf surat berharga, wakaf hak atas kekayaan intelektual, dan wakaf hak sewa dengan sejumlah permasalah hukum barunya?

Di samping itu, hubungan dengan program "Anonimisasi" (pengkaburan identitas putusan), maka produk putusan Hakim Peradilan Agama termasuk di dalamnya putusan perkara wakaf, harus benar- benar mengedepankan kualitas, baik kualitas sistimatika hukumnya, bahasa hukum yang digunakannya, maupun substansi hukum yang dihasilkannya.

\section{Simpulan}

Pendapat ulama fiqih mengenai objek wakaf memperlihatkan bahwa syarat-syarat benda wakaf (harus benda, bermanfaat, tidak sekali pakai, tidak haram zatnya, dan harus 
milik wakif secara sempurna) tidak didukung hadis secara khusus dan mereka menggunakan ayat-ayat al-quran dan hadis yang bersifat umum. Oleh karena itu, penentuan syarat-syarat objek wakaf termasuk wilayah ijtihadi.

Sekarang uang menempati posisi penting dalam kegiatan transaksi ekonomi di berbagai negara di dunia, karena uang sekarang tidak hanya berfungsi sebagai alat tukar, tetapi sudah dianggap sebagai benda yang meskipun terjadi silang pendapat di antara pakar fiqih dapat diperdagangkan. Oleh karena itu, ulama di pakistan, Abdul Manan, sudah membolehkan adanya wakaf uang dengan istilah cash waqf (yang diterjemahkan ke dalam bahasa Indonesia menjadi wakaf tunai), terjemahannya agak keliru karena mengaburkan gagasan pokoknya.

\section{Daftar Pustaka}

Abu Bakr Muhammad Ibn Ahmad Ibn Sahl al-Syarkhasi, Kitab alMabsuth, Dar al-Kutub al-Ilmiyah, Beirut, 2001.

Ahmad Warson, Kamus al Munawir, al-Munawir, Yogyakarta, tt.

Bukhari, Shahih al-Bukhari, Thaha Putra, Semarang, 1981 .

Juhaya S. Praja, Perwakafan di Indonesia: Sejarah Pemikiran Hukum dan Perkembangannya, Yayasan Piara, Bandung, 1993.

M. Yahya Harahap, Kedudukan, Kewenangan dan Acara Pengadilan Agama, Pustaka Kartini, Jakarta, 1997.

Malik Ibn Anas, al-Mudawwanat al-Kubra, Dar al-Kutub al-Ilmiyah, Beirut, $\mathrm{tt}$.

Muhammad Ibn Idris al-Syafi'i, al-Umm, Vol. III, Maktabah Kuliyat al-Azhariyah, Mesir, tt. 
Muhammad Mushthafa Salabi, Muhadlarat fi al-Wakf wa alWashiyyat, Dar al-Ta'lif, Mesir, 1957.

Muslim, Shahih Muslim, Dahlan, Bandung, tt.

Sajtipto Raharjo, Ilmu Hukum, Citra Aditya Bhakti, Bandung, 1996.

Sayyid Sabiq, Fiqih Sunnah, Dar al-Fikr, Beirut, 1983.

Taqiyah al-Din Abi Bakr Ibn Muhammad al-Husaini al-Dimasqi, Kifayat al-Akhyar Fi Hall Ghayat al-Ikhtishar, Thaha Putra, Semarang, tt.

Wahbah az-Zuhaily, al-Figh al-Islami wa Adillatuh, Dar al-Fikr, Beirut, tt. 